\title{
The toxic mechanism and bioactive components of Chinese leek root exudates acting against $F$ usarium oxysporum f. sp. cubense tropical race 4
}

\author{
Cunwu Zuo • Chunyu Li • Bin Li • Yuerong Wei • Chunhua Hu • Qiaosong Yang • \\ Jing Yang • Ou Sheng • Ruibin Kuang • Guiming Deng • Manosh Kumar Biswas • \\ Ganjun Yi
}

Accepted: 19 June 2015 / Published online: 30 June 2015

(C) The Author(s) 2015. This article is published with open access at Springerlink.com

\begin{abstract}
Fusarium wilt is one of the most serious threats to banana production worldwide. The disease is caused by the soil-borne fungal pathogen Fusarium oxysporum f. sp. cubense (Foc), especially tropical race 4 (Foc TR4). It has been reported that crop rotation and intercropping of Chinese leek (Allium tuberosum) with banana can effectively reduce incidence of the disease in the field. In this study, we investigated the toxic mechanism and bioactive compounds of Chinese leek root exudates (CLREs) acting against Foc TR4. In vitro experiments showed that CLREs inhibit the germination and growth of Foc TR4, initiate the accumulation of reactive oxygen species (ROS), and trigger a decrease in the mitochondrial transmembrane potential $(\Delta \Psi \mathrm{m})$. In addition, it induced decreases in the expression of
\end{abstract}

Cunwu Zuo, Chunyu Li and Bin Li contributed equally to this work.

C. Zuo $\cdot$ C. $\mathrm{Li} \cdot$ B. Li $\cdot$ Y. Wei $\cdot$ C. Hu $\cdot$ Q. Yang $\cdot$ O. Sheng $\cdot$ R. Kuang $\cdot$ G. Deng $\cdot$ M. K. Biswas $\cdot$ G. Yi $(\bowtie)$ Institute of Fruit Tree Research, Guangdong Academy of Agricultural Sciences, Guangzhou 510640 Guangdong Province, China

e-mail: yiganjun@vip.163.com

C. Zuo $\cdot$ C. $\mathrm{Li} \cdot$ B. Li $\cdot$ Y. Wei $\cdot$ C. Hu $\cdot$ Q. Yang $\cdot$ O. Sheng $\cdot$

R. Kuang $\cdot$ G. Deng $\cdot$ M. K. Biswas $\cdot$ G. Yi

Key Laboratory of South Subtropical Fruit Biology and Genetic Resource Utilization, Ministry of Agriculture, Guangzhou 510640 Guangdong Province, China

C. Zuo $\cdot$ B. Li $\cdot$ J. Yang

Collage of Life Science, South China Agricultural University,

Guangzhou 510640 Guangdong Province, China ergosterol biosynthesis genes, and up-regulated the expression of genes associated with autophagy. Dimethyl trisulfide, dimethyl disulfide, 2-propenyl methyl disulfide, 2-propenyl methyl trisulfide, and 2-methoxy-4vinylphenol are major components of CLREs volatiles, and strongly inhibit Foc TR4 development. These results suggest that CLREs induce cell death in Foc TR4 by inducing oxidative bursts, mitochondrial impairment, and plasma membrane depolarization. In addition, sulfur and phenolic compounds contribute to its antifungal activity.

Keywords Chinese leek root exudates (CLREs) .

Fusarium oxysporum f. sp. Cubense tropical race 4 (Foc TR4) · Toxic mechanism · Bioactive compounds

\section{Introduction}

Fusarium wilt (Panama disease), one of the most destructive fungal diseases affecting banana plants worldwide, is caused by Fusarium oxysporum f. sp. cubense (Foc) (Ploetz 1990, 2006; Moore et al. 2001; Fourie et al. 2011), a cosmopolitan soil-borne fungus that colonizes and blocks the vascular systems of host plants. The pathogen can be classified into four races according to host type (Ploetz 2006). Among them, Tropical race 4 (Foc TR4) is highly pathogenic to almost all banana cultivars, and has destroyed thousands of hectares of Cavendish bananas in tropical and subtropical countries and regions such as Indonesia, Malaysia, Philippines, 
China, and the Northern Territory of Australia (Molina et al. 2007; Su et al. 1986). In China, Fusarium wilt has been detected in all provinces with major banana industries, such as the Guangdong, Hainan, Fujian, Guangxi, and Yunnan provinces ( $\mathrm{Li}$ et al. 2013a). Once Foc is introduced to or found in banana plantations, Fusarium wilt is difficult to eradicate (Viljoen 2002).

Chinese leek (Allium tuberosum) is a common vegetable in China. It can be easily biodegraded with little residue and without adverse effects on other plants; thus, it offers an environmental approach to control the disease. The intercropping or crop rotation of Chinese leek with banana could reduce the incidence of Fusarium wilt in China. Subsequent field and greenhouse studies have shown that Chinese leek has a suppressive effect on Fusarium wilt when grown in rotation with banana plants (Huang et al. 2012). Chinese leek extracts significantly inhibited the mycelial growth and spore germination of Foc in vitro (Zhang et al. 2013).

Natural products from plants and bio-control fungus as well as commercially available fungicides could control the disease in the field (Washington et al. 1999). In most cases, apoptosis-like cell death was activated via different routes, such as oxidative bursts, phosphatidylserine (PS) externalization, and DNA fragmentation (Sharon et al. 2009). Farnesol, secreted by the fungus Candida albicans, could induce apoptosis in Aspergillus nidulans, a process which mitochondria and reactive oxygen species (ROS) participate in (Semighini et al. 2006). Fungal autophagy plays an important role in both the initial protection of the cells of individuals from unwanted cell death and pathogenesis (Sharon et al. 2009). In filamentous fungi, autophagy is typically induced by carbon and nitrogen starvation (Pinan-Lucarré et al. 2005), but it can also be caused by stress or exposure to antifungal compounds (Sharon et al. 2009).

Most fungicides impair the essential processes of targeted fungi, via such methods as the inhibition of cell wall formation, alteration of membrane permeability, and interference with RNA, protein, or amino acid synthesis (Sundriyal et al. 2006; Steffens et al. 1996). In fungi, glucan polymers and chitin are major components of the cell wall, and ergosterol is essential for the maintenance of plasma membrane integrity (Wessels 1994). As inhibitors of $\beta 1-3$ glucan synthase, the antifungal drugs known as echinocandins interfere with the synthesis of the fungal cell wall (Tawara et al. 2000). Application of the polyene antifungal amphotericin B
$(\mathrm{AmB})$ first causes the formation of aqueous pores in the fungal plasma membrane, and then alters membrane permeability, ultimately leading to cell death (Bolard 1991).

However, the toxic mechanisms and bioactive compounds of Chinese leek are poorly understood. In this study, the bioactive compounds and antifungal activity of Chinese leek root exudates (CLREs) acting on Foc TR4 spores were examined, and the potential mechanism of inhibition was elucidated.

\section{Materials and methods}

Preparation of root exudates and fungal isolates

Zigen-Chinese Leek (Allium tuberosum, Ji County Seeds Co., Tianjin, China) seeds were sown in the HongMei experimental field at the Institute of Fruit Tree Research, Guangzhou, in March 2012. The planting site was prepared and managed using established cultivation practices, without the application of either pesticides or fungicides. One year after planting, the Chinese leek plants were collected from the field and washed with sterile water to remove surface-adhering exudates and soil, then used for exudates collection. The Chinese leek seedlings were first placed in plastic containers filled with 21 of sterile distilled water and maintained at room temperature $\left(23-28^{\circ} \mathrm{C}\right)$, with each plate containing 20 plants. After 20 day of growth, the roots were weighed to determine their root exudates concentrations. To remove root sheaths and border-like cells, the root exudates were collected via centrifugation, then filtrated with nylon filters (pore size $=0.22 \mu \mathrm{m}$ ). The Chinese leek root exudates (CLREs) were subsequently dissolved in sterile deionized water, and the stock concentration was adjusted to $10 \mathrm{~g}$ roots $/ \mathrm{ml}$ using a vacuum freeze-drying apparatus (LGJ-10D Vacuum Freeze Drier, Four-Ring Science Instrument Plant Beijing Co., Beijing, China).

Foc TR4 isolate GD-13 (ACCC 37969, VCG 01213/ 16) was used to test the antifungal activity of CLREs in vitro. The strain was cultured on potato-dextrose agar (PDA) in 9-cm plastic dishes at $28^{\circ} \mathrm{C}$ for 7 days, after which the fungal mycelia was collected and inoculated into $50 \mathrm{ml}$ potato dextrose broth (PDB) in an $100 \mathrm{ml}$ Erlenmeyer flask, then placed on a rotary shaker at $200 \mathrm{rpm}$. After $48 \mathrm{~h}$, the spore suspension was filtered using sterile gauze, centrifuged at $1000 \mathrm{rpm}$ for $5 \mathrm{~min}$, 
and resuspended in PDB. The conidial suspensions were adjusted to $2 \times 10^{6}$ conidia $/ \mathrm{ml}$.

\section{Foc TR4 viability assay}

Conidia were incubated with $50 \mu \mathrm{M}$ fluorescein diacetate (FDA, life technologies Inc., Gaithersburg, $\mathrm{MD}$ ) for $10 \mathrm{~min}$ in the dark at room temperature, then rinsed twice in ultrapure water. The fluorescent signal was monitored using a Zeiss LSM 710 Laser Confocal Scanning Microscope (LCSM) (LSM710/ConfoCor2, CarlZeiss, Jena, Germany). The FDA fluorescence analysis was performed using an excitation wavelength of $488 \mathrm{~nm}$ and an emission wavelength of $521 \mathrm{~nm}$. Briefly, $150 \mu \mathrm{l}$ of the conidial suspensions prepared above, along with CLREs, were pipetted into each well of a 96-well plate to make up final CLRE concentrations of $2,4,6,8$, and $10 \mathrm{~g} / \mathrm{ml}$. The plates were then incubated at $28^{\circ} \mathrm{C}$ in darkness for $24 \mathrm{~h}$. The experiment was replicated three times. For the control, sterile water was added to the Foc TR4 conidial suspensions.

\section{Germination test of Foc TR 4 conidia}

A test to determine the germination rate of CLREstreated Foc TR4 conidia was performed as described by Li et al. (2011). CLREs were mixed with the conidial suspension to achieve the indicated concentrations. For the control, sterile deionized water was used instead of CLREs. The treated conidia were incubated at $28^{\circ} \mathrm{C}$ for 1-6 h, and each treatment was replicated three times. One drop of the suspension from each treatment was placed on a slide and detected under a microscope. In each sample, five fields were observed at random, and the number of germinated conidia was counted. The germination ratio was calculated as a percentage, using the following equation:

\section{Germination ratio (\%)$$
=(\text { germinated conidia } / \text { total conidia }) \times 100 \% .
$$

To exclude the influence of the osmotic pressure and $\mathrm{pH}$ of the CLREs ( 2 and $8 \mathrm{~g} / \mathrm{ml}$ ) on Foc TR4 growth, the two traits were measured using a freezing point osmometer (OM-815 M, Löser, Germany) and a Sartorius basic pH-Meter PB-10 (China), respectively.
Measurement of reactive oxygen species (ROS) production

2',7'-Dichlorlfluorescein diacetate $\left(\mathrm{H}_{2} \mathrm{DCFDA}\right.$, Life technologies Inc., Gaithersburg, MD) is nonfluorescent until hydrolyzed by intracellular esterase and oxidized by ROS to form the highly fluorescent dichlorofluorescein (DCF). Thus, intracellular ROS production could be measured by monitoring the fluorescence of DCF (Zhang and Chen 2011). In addition, the nuclei of dead conidia could be stained with the red fluorescent dye Propidium iodide (PI, Life technologies Inc., Gaithersburg, MD) (Jones and Kniss 1987). In order to detect the relationship between ROS production and the CLREs-induced cell death of Foc TR4, the conidia were double-stained with $\mathrm{H}_{2}$ DCFDA and PI. After being treated with different concentrations of CLREs, $300 \mu \mathrm{l} \mathrm{Foc} \mathrm{TR4} \mathrm{conidia} \mathrm{were} \mathrm{incubated} \mathrm{with}$ $\mathrm{H}_{2}$ DCFDA for $30 \mathrm{~min}$ and PI for $10 \mathrm{~min}$ in the dark. In order to remove the $\mathrm{H}_{2}$ DCFDA and PI, the medium was washed three times with a phosphate buffer solution (PBS, $\mathrm{pH}=7.4$ ). Fluorescence was analyzed using a multifunctional microplate reader (Varioskan Flash, Thermo Scientific, USA) and the LCSM.

Changes in the mitochondrial transmembrane potential $(\Delta \Psi \mathrm{m})$

Changes in $\Delta \Psi \mathrm{m}$ were assessed by staining the conidia with JC-1 (Life technologies Inc., Gaithersburg, MD), which is selectively incorporated into the mitochondria of fungal conidia. The fluorescence shifted from orange to green, which indicated a decline in the $\Delta \Psi \mathrm{m}$ of the conidia (Yamada et al. 2010). The Foc TR4 conidia were incubated in a 96-well plate with CLREs, at the indicated concentrations for the aforementioned periods. They were then incubated with JC-1 and kept in the dark for $30 \mathrm{~min}$ at $28^{\circ} \mathrm{C}$. After incubation, the treated conidia suspensions were washed three times with PBS and analyzed immediately using LCSM at excitation wavelengths of $488 \mathrm{~nm}$ and emission wavelengths of 530 and $590 \mathrm{~nm}$. The $\Delta \Psi \mathrm{m}$ was measured using a multifunctional microplate reader as chi-2 (intensity of fluorescence in red)/chi-1 (intensity of fluorescence in green).

Real time quantitative PCR (qRT-PCR)

Treated and untreated conidia suspensions were prepared after $0.5,2,4$, and $8 \mathrm{~h}$. The total RNA of each 
sample (including the replicates) was extracted using a Fungal RNA output kit (Tiandz Inc., Beijing, China). A PrimeScript ${ }^{\mathrm{TM}}$ RT Reagent kit with gDNA Eraser (TAKARA, Dalian) was used for RNA purification and the reverse-transcription of cDNA. The sequence of each gene was checked using the BLAST tool from the National Center for Biotechnology Information (NCBI, http://archive-dtd.ncbi. nlm.nih.gov/), and downloaded from the online resources of the Broad Institute (http://www. broadinstitute.org/). Primers were designed using the online software program Primer 3 (http:// primer3.ut.ee/). The ssequence of each primer is listed in Table 1. qRT-PCR analysis was conducted using an CFX96 Touch $^{\text {TM }}$ Real-Time PCR Detection System (Bio-Rad, USA) with SYBR ${ }^{\circledR}$ Premix Ex $\mathrm{Taq}^{\mathrm{TM}}$ II (Tli Rnase H Plus, TAKARA, Dalian). Dissociation curve were analyzed before the qRTPCR assay for their specificity. The relative expression levels were calculated by comparative $-\Delta \Delta \mathrm{Ct}$, and normalized to actin (López-Berges et al. 2010, 2012).

Bio-control test in vitro

An in vitro bioassay system was used to evaluate the effect of CLREs on the development of Fusarium wilt symptoms in banana plants (Wu et al. 2010). Briefly, the medium for the interaction system (MIS) (lower than $40{ }^{\circ} \mathrm{C}$ ) was mixed with CLREs to achieve the indicated concentrations, then mixed with the Foc TR4 conidia suspensions. For the control, an equivalent volume of sterile deionized water was added to the MIS, instead of CLREs. To simulate intercropping, the Baxi banana plantlets (AAA, susceptible cultivar) were immediately planted in the mixture and inoculated with Foc TR4. For crop rotation simulation, plantlets were planted in medium after Foc TR4 was added to the mixture after $24 \mathrm{~h}$, and then co-cultured at $27^{\circ} \mathrm{C}$ for a 12 -h daynight light photo-period. The disease incidence and the growth of Foc TR4 in the different treatments was recorded 15 days later. Ten plants were randomly obtained from each treatment to assess the IDI, which was calculated using the following equation: Integrated disease index (IDI) $=$ average of each plantlet disease index/highest disease index $\times$ 100\% (Li et al. 2011; Smith et al. 2008).

Analysis of the allelochemical components and the bioactivity

To identify the allelochemicals of the CLREs, the volatile and non-volatile phases were extracted via steam distillation (Ozel and Kaymaz 2004). Then, the volatile phase was analyzed using a GC/MS system (Voyager, Finnigan, USA) equipped with a HP-INNOWAX fused silica capillary column $(30 \mathrm{~m} \times 0.32 \mathrm{~mm} \times 0.25 \mathrm{~mm})$. The GC parameters were determined to be as follows: carrier gas helium; splitless injection; injection port temperature $220{ }^{\circ} \mathrm{C}$; oven temperature initially $40{ }^{\circ} \mathrm{C}$ for $3 \mathrm{~min}$, then increased to $310{ }^{\circ} \mathrm{C}$ at a rate of

Table 1 Primers used in this study

\begin{tabular}{lllllll}
\hline $\begin{array}{l}\text { Target } \\
\text { gene }\end{array}$ & $\begin{array}{l}\text { Foc } \\
\text { orthologue }\end{array}$ & $\begin{array}{l}\text { Length of } \\
\text { Fragment }\end{array}$ & Name & Seq (5-3) & Name & Seq (5-3) \\
\hline ATG1 & FOIG_05125 & 155 & ATG 1-1 F & TAGTCCCGGATCAGCCTCTAG & ATG 1-1 R & GGGCCTGAGGAGTTGGATATG \\
ATG8 & FOIG_07869 & 235 & ATG 8-1 F & CTCTGACCGCATTCCCGTTAT & ATG 8-1 R & ACCGTCCTCATCCTTGTGTTC \\
ATG15 & FOIG_08873 & 206 & ATG 15-1 F & CACCGAAACCACCACAACATC & ATG 15-1 R & TAGTCGTCTTGTCCTTGCACC \\
CHI4 & FOIG_00580 & 164 & CHI 4-1 F & TTACCTGGCCTTCTCGTTGTC & CHI 4-1 R & TCACCAGCTGTCTTTCGAGTC \\
CHI5 & FOIG_06738 & 188 & CHI 5-2 F & ACTCTCTTCCTACGACGGTGA & CHI 5-2 R & ACAGAGCAGACACTTGGATGG \\
CHI7 & FOIG_06735 & 261 & CHI 7-2 F & GATGCCAGCACCAGTCTAGTT & CHI 7-2 R & GTAGGGAGTAACGCATCGGAG \\
CYP51-2 & FOIG_10483 & 178 & CYP51-2-2 F & AAGGGTAGTGGGGAGACAGTT & CYP51-2-2R & GACCAGGCTTCTCAATGTGGA \\
CYP51-3 & FOIG_00890 & 212 & CYP51-3-2 F & CTGATTTGCCTCCCCTGACTT & CYP51-3-2R & GAAGTAGGCCGAGTCAGTAGC \\
GEL1 & FOIG_07190 & 186 & GEL1-1 F & CGGTCCTTCTTACAATGCCG & GEL1-1R & CGGGCCTTGATGTAGTTTCG \\
GEL2 & FOIG_03620 & 243 & GEL2-1 F & GCGCTCAACTCTTACTCATGG & GEL2-1R & GACGAGGCCATAGTTGTTGTC \\
GEL3 & FOIG_06516 & 182 & GEL3-2 F & TATCCCTCTCCTCAAGCAGCT & GEL3-2R & CGTACAGCTCAACATCCCACT \\
ACT1 & FOIG_02823 & 279 & act1-1 F & CTCCCATCAACCCCAAGTCC & act1-1R & AGAAAGTGTAACCGCGCTCA \\
\hline
\end{tabular}


$10{ }^{\circ} \mathrm{C} / \mathrm{min}$, and completed at $250^{\circ} \mathrm{C}$ for $5 \mathrm{~min}$. The MS conditions were as follows: Electron impact ionization (EI+) mode; electron energy $70 \mathrm{eV}$; ionization voltage $4 \mathrm{~V}$; Lens 1:3 V, Lens 2:100 V; ion energy $0.6 \mathrm{eV}$; ion energy ramp $2 \mathrm{mV} / \mathrm{amu}$; transfer line heater $230^{\circ} \mathrm{C}$; ion source temperature $200{ }^{\circ} \mathrm{C}$. The obtained mass spectra were compared to those in the NIST 98 MS library database.

Dimethyl trisulfide and 2-methoxy-4-vinylphenol were obtained from Sigma-Aldrich (Shanghai, China), and methyl 2-propenyl disulfide and methyl 2propenyl trisulfide were purchased from Kangmanlin Chemical Industry Co. (Nanjing, China). Each compound was dissolved in dimethyl sulfoxide (DMSO) to create stock solutions. To identify the antifungal compounds in the CLREs, the viability of Foc TR 4 samples treated with the pure compounds identified in the GC/MS assay was determined via FDA staining. The fluorescent signal was monitored via LCSM and a multifunctional microplate reader. Each treatment was replicated 3 times, and DMSO served as the control, rather than the pure compounds. The effects of pure compounds on Foc TR4 conidia were expressed as \% viability, by comparing the viability of the treated conidia to the viability of the control conidia by using the following formula:

Viability $(\%)=$ treatment/control $\times 100 \%$.

Statistical analysis

The data were statistically analyzed using Origin 8.0 (Microcal Software, Northampton, MA, USA), and significant differences were detected using the $t$-test $(P<0.05)$.

\section{Results}

Growth and germination of Foc TR4 were inhibited by CLREs

Both viability and germination ratio of Foc TR4 were significantly inhibited when the concentration of CLREs was greater than or equal to $2 \mathrm{~g} / \mathrm{ml}$. As the concentration of CLREs increased, the change in the viability of Foc TR4 was indicated by the disappearance of the
Fig. 1 Viability of Foc TR4 treated with CLREs for $24 \mathrm{~h}$. The control group (a) and conidia treated with $2 \mathrm{~g} / \mathrm{ml}$ (b) and $8 \mathrm{~g} / \mathrm{ml}$ (c) CLREs were incubated in $50 \mu \mathrm{M}$ FDA for $10 \mathrm{~min}$ at room temperature and then observed by LCSM. Viable conidia were green. Scale bars $=50 \mu \mathrm{m}$. $\mathbf{d}$ the viability of Foc TR4 in different groups was quantified. Each data point is the mean \pm SE of three replicates. Statistical analysis was performed using the $t$-test, and asterisks indicate a significant difference from the control, at $P<0.05$ (*), and $P<0.01$ (**)
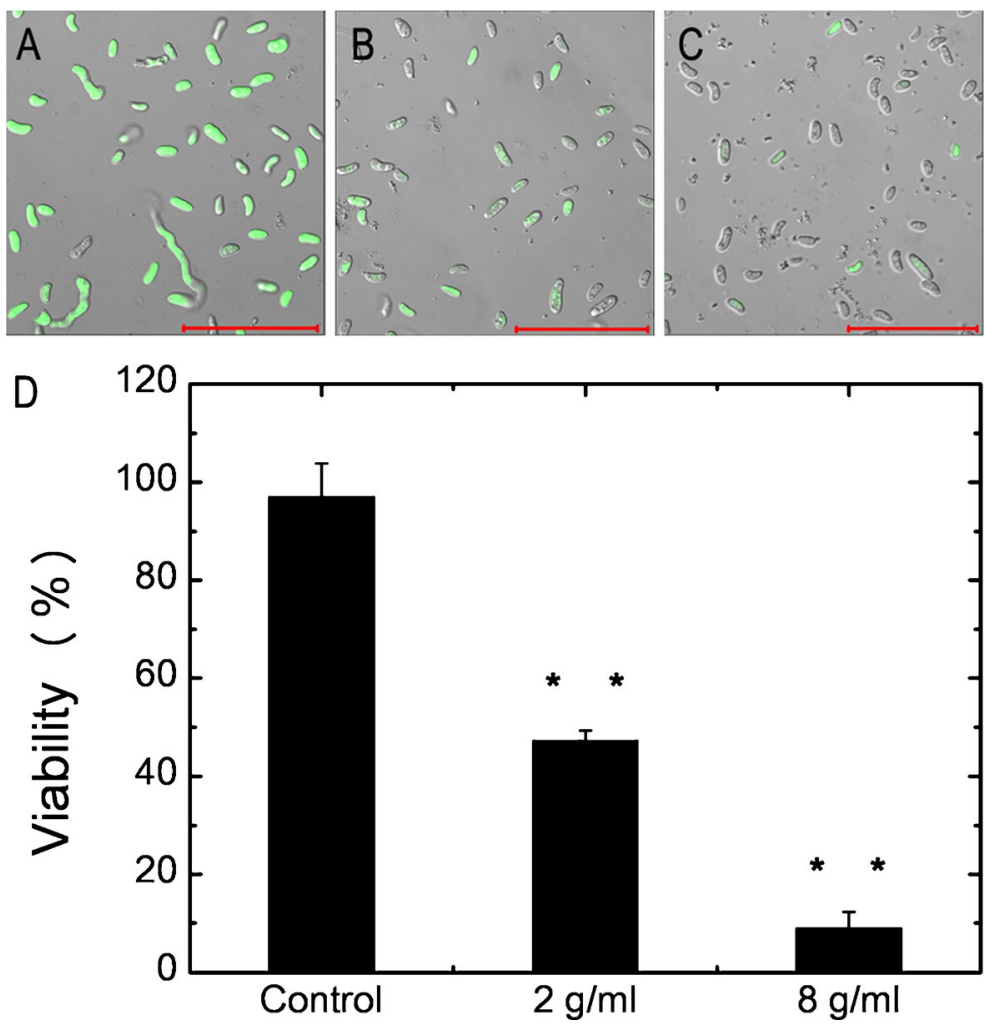


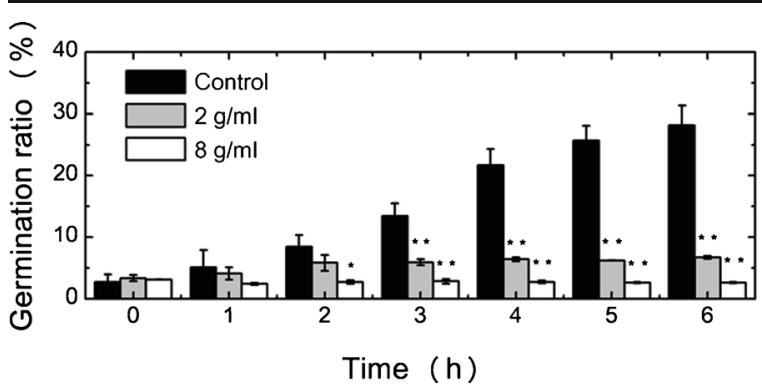

Fig. 2 Changes in the germination ratio (\%) of Foc TR4 conidia treated with CLREs. Compared to the control, the germination ratio was significantly decreased when conidia were exposed to $2 \mathrm{~g} / \mathrm{ml}$ and $8 \mathrm{~g} / \mathrm{ml}$ CLREs. Data are represented as the mean \pm SE of three independent replicates, and the asterisks represent significant differences from the control, with $P<0.05\left(^{*}\right)$ or $P<0.01(* *)$

fluorescence of the FDA-tagged spores (Fig. 1a-c). Viability was reduced by about 50 and $10 \%$ by treatment with 2 and $8 \mathrm{~g} / \mathrm{ml}$ of CLREs, respectively. In the control group, the germination ratio of the Foc TR4 conidia increased from $2.67 \pm 0.7 \%$ to $28.2 \pm 3.1 \%$ over a period of $6 \mathrm{~h}$. However, when 2 or $8 \mathrm{~g} / \mathrm{ml}$ of CLREs were mixed with the conidia, germination was significantly inhibited (Fig. 2).

The growth and germination of Foc TR4 were not affected by the osmotic pressure and $\mathrm{pH}$ of the tested CLRE solutions. The osmotic pressure of the 2 and $8 \mathrm{~g} /$ $\mathrm{ml} \mathrm{CLRE} \mathrm{solutions} \mathrm{was} 254.67 \pm 11.37$ and $109 \pm 7$ os$\mathrm{mol} / \mathrm{kg} \mathrm{H}_{2} \mathrm{O}$, respectively (data not shown). There were no significant differences in viability when Foc TR4 conidia were grown in PDB to which different concentrations of sucrose had been added to induce osmotic pressure changes from 100 to $300 \mathrm{osmol} / \mathrm{kg} \mathrm{H}_{2} \mathrm{O}$. The $\mathrm{pH}$ values of the two CLREs solutions were as high as $5.84 \pm 0.1$ and $6.01 \pm 0.09$, but Fusarium species can grow normally on media within this $\mathrm{pH}$ range (Wheeler et al. 1991).

The accumulation of ROS and decrease of $\Delta \Psi \mathrm{m}$ in $F o c$ TR4 was elicited by CLREs

To elucidate the mechanism of the action of CLREs against Foc TR4, changes in ROS production and
Fig. 3 ROS production index and spore viability of Foc TR4 conidia indicated by DCF and PI fluorescence intensity. (1): ROS production of mycelia and conidia induced by treatment with $2 \mathrm{~g} / \mathrm{ml}$ of CLREs for the indicated time. Production of ROS in mycelia and conidia was increased after $10 \mathrm{~min}$ and $80 \mathrm{~min}$ of treatment. However, cell death (red color due to PI staining) was discovered after the increase in ROS. Scale bars $=20 \mu \mathrm{m}$. (2): ROS increase in Foc conidia and mycelia treated with CLREs was time dependent
(1)

DIC

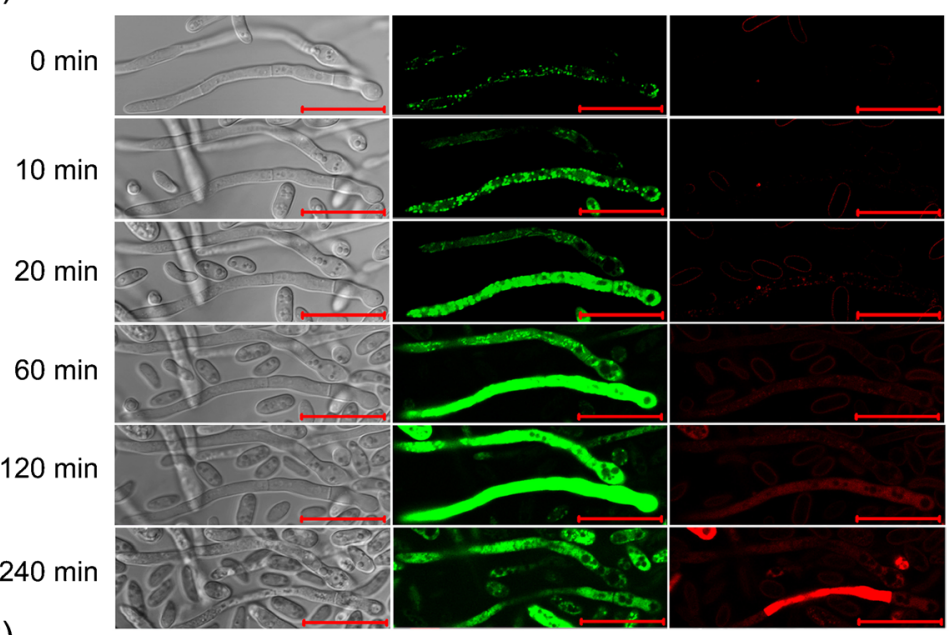

(2)

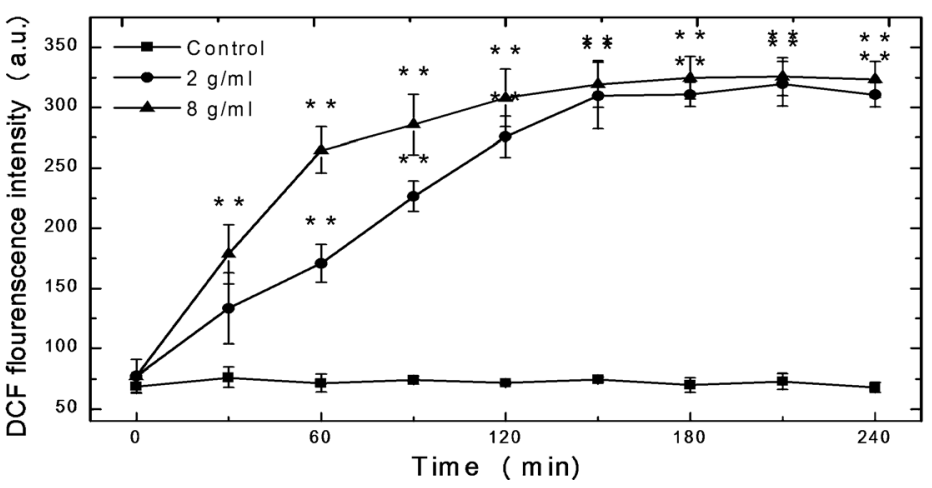


$\Delta \Psi \mathrm{m}$ were examined. The production of ROS in Foc TR4 mycelia and conidia was significantly induced by $60 \mathrm{~min}$ after treatment with either 2 or $8 \mathrm{~g} / \mathrm{ml}$ of CLREs (Fig. 3(2)). During normal metabolism, the ROS production index of Foc conidia was $71.2 \pm 1.05$, but increased to $170.7 \pm 15.8$ and $264.8 \pm 18.960 \mathrm{~min}$ after treatment with 2 and $8 \mathrm{~g} / \mathrm{ml}$ of CLREs, respectively. The highest ROS production index was observed $210 \mathrm{~min}$ after treatment with $8 \mathrm{~g} / \mathrm{ml}$, and at $325.7 \pm$ 15.7 was five times higher than that of the control (Fig. 3(2)). After induction of ROS, Foc TR4 conidia and mycelium were stained by special dye PI (Fig. 3(1)), and indicated that ROS production was a factor under CLREs-induced cell death.

As shown and quantified in Fig. 4, Foc TR4 conidia and mycelia treated by CLREs and stained with JC-1 displayed a shift from red-orange to greenish yellow fluorescence, which is indicative of a loss or collapse of $\Delta \Psi \mathrm{m}$. Quantitative analysis showed that the depolarization of $\Delta \Psi \mathrm{m}$ that occurred when Foc TR4 was exposed to CLREs occurred in a time- and concentrationdependent manner (Fig. 4d). Significant decreases in $\Delta \Psi \mathrm{m}$ occurred after $F O c$ TR 4 samples were treated with 2 or $8 \mathrm{~g} / \mathrm{ml}$ of CLREs for $3 \mathrm{~h}$. As shown in Fig. 4d, the chi-2/chi-1 value was 1.72 to 1.83 under normal conditions, and decreased to $1.38 \pm 0.11$ and $1.04 \pm 0.06$ $3 \mathrm{~h}$ after the conidia had been exposed to 2 and $8 \mathrm{~g} / \mathrm{ml}$ CLREs, respectively. Overall, these results suggest that ROS production and the decline of $\Delta \Psi \mathrm{m}$ are early features of the CLRE-induced cell death of FocTR4 mycelia and conidia.

Foc TR4 ergosterol synthesis genes were repressed by CLREs

Mitochondria are both the source and target of ROS (Simon et al. 2000). However, our observations show that CLRE-induced ROS accumulation in FOC TR4 occurred earlier than the decrease in $\Delta \Psi \mathrm{m}$ (Figs. 3 and 4). Because of this, we tested the hypothesis that CLREs could target cell organelles besides mitochondria. Chitin synthase genes $(C H I)$ and beta- $(1,3)-$ glucanosyltransferase genes $(G E L)$ play an active role in fungal cell wall biosynthesis (Bowman and Free 2006). In addition, the fungal cytochrome $P 450$ lanosterol C-14 $\alpha$-demethylase genes (CYP51) are essential for the biosynthesis of ergosterol, which is responsible for fungal membrane integrity (Alvarez et al. 2007). In order to detect other CLRE target sites, the expression rates of seven genes related to cell wall and
Fig. $4 \Delta \Psi \mathrm{m}$ changes in $F o c$ TR4 treated with root exudates for $8 \mathrm{~h}$ and detected with $\operatorname{LCSM}(\mathbf{a}, \mathbf{b}, \mathbf{c}$, Scale bars $=20 \mu \mathrm{m})$, then analyzed using quantitative analysis (d). Under normal conditions, Foc TR4 mitochondria could be stained with JC-1, and exhibited red or orange fluorescence (a), but exhibited green fluorescence after the conidia were exposed to $2 \mathrm{~g} /$ $\mathrm{ml}(\mathbf{b})$ and $8 \mathrm{~g} / \mathrm{ml}$ (c) of CLREs for $4 \mathrm{~h}$, indicating a reduction of $\Delta \Psi \mathrm{m}$
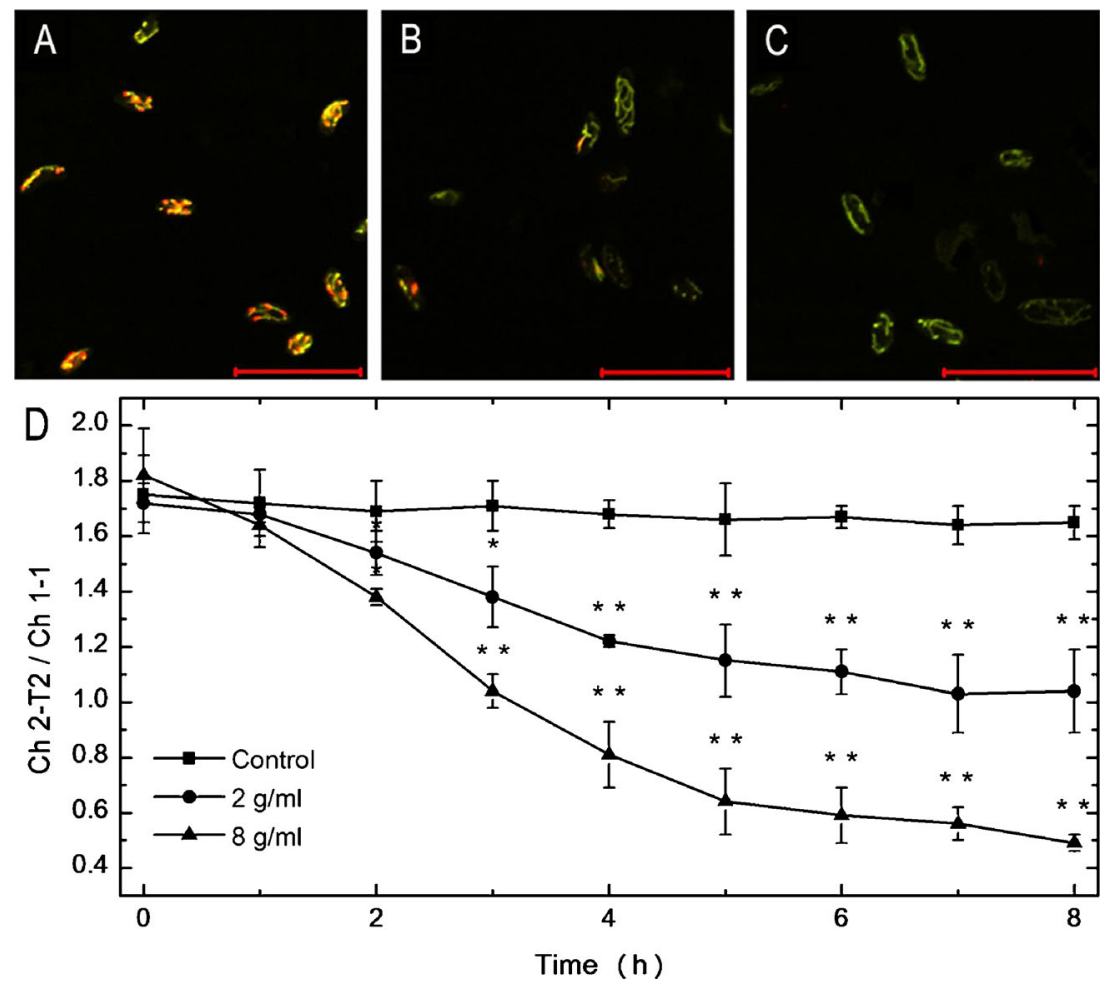
plasma membrane synthesis in Foc TR4 (CHIA, CHI5, CHI7, GEL1, GEL3, CYP51-2, and CYP51-3) were determined via a qRT-PCR assay. There were no significant differences between the control and treated groups in the expression rates of five cell wall-related genes (data not shown). Nevertheless, when conidia were grown in PDB, the expression rates of 2 CYP51s, CYP51-2 and CYP51-3, were up-regulated from 0.5 to $2 \mathrm{~h}$, but strongly repressed from 0.5 to $4 \mathrm{~h}$ after the CLREs treatment (Fig. 5). These results suggested that the synthesis of ergosterol was inhibited by CLREs.

\section{Autophagy of FocTR4 was induced by CLREs}

Autophagy is a self-degradative process involved in responses to stresses such as treatment with antifungal

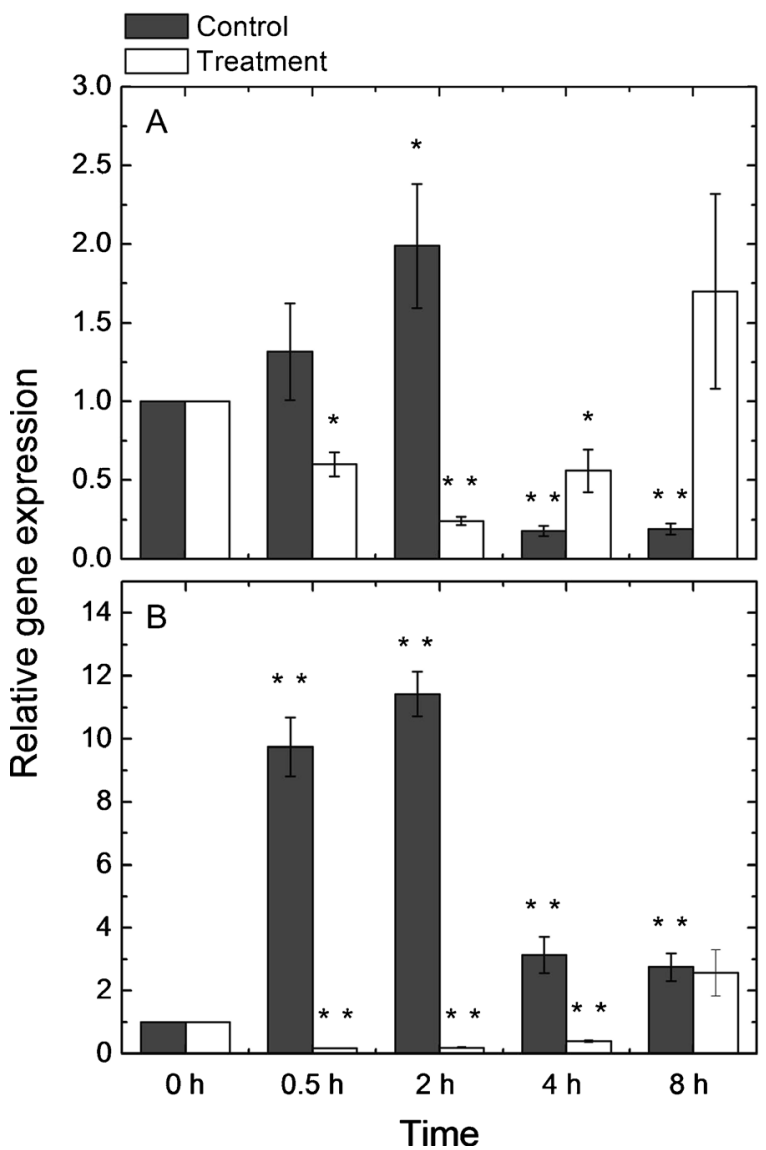

Fig. 5 The expression rates of the membrane integrity related genes CYP51-2 (a) and CYP51-3 (b) were analyzed using qRT-PCR, after the FOC TR4 conidia were exposed to $2 \mathrm{~g} / \mathrm{ml}$ CLREs for different time. Each data point is the mean $\pm \mathrm{SE}$ of three replicates. Statistical analysis was performed using the $t$-test: asterisks indicate a significant difference from the control: $P<0.05(*), P<0.01(* *)$ drugs (Glick et al. 2010; Richetta and Faure 2013). Autophagy-related $(A T G)$ genes are either involved in autophagy, or responsible for the activation of specific autophagy-related pathways in response to stress
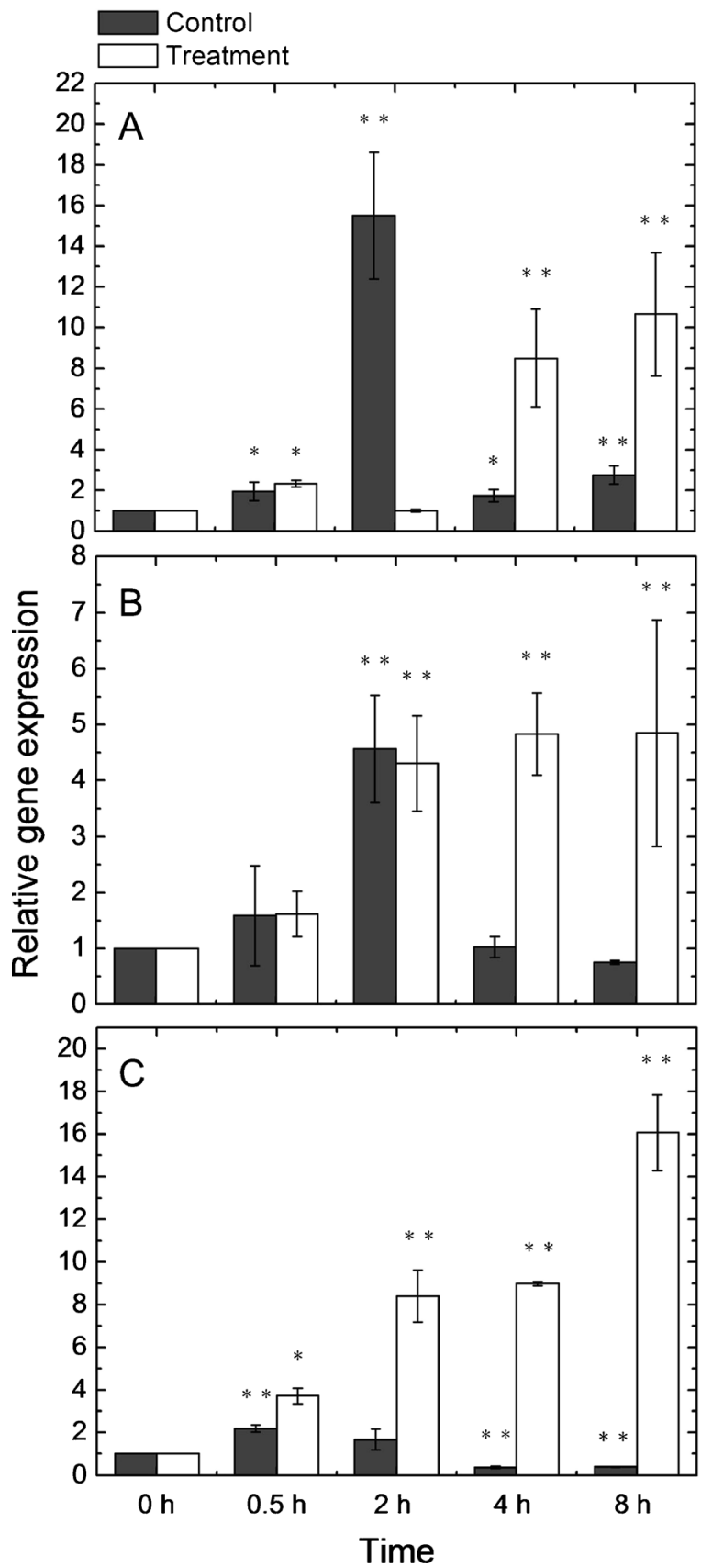

Fig. 6 The expression rates of autophagy-related genes $A T G 1$ (a), $A T G 8$ (b), and ATG15 (c) were validated using qRT-PCR, after conidia were treated with $2 \mathrm{~g} / \mathrm{ml}$ CLREs. Statistical analysis was performed using the $t$-test, asterisks indicate a significant difference from the control: $P<0.05\left(^{*}\right)$ or $P<0.01(* *)$ 
(Sharon et al. 2009). To investigate the adaptive reaction of Foc TR4 exposed to CLREs, the expression rates of $A T G 1, A T G 8$, and $A T G 15$ genes were investigated via a qRT-PCR assay. As shown in Fig. 6, in the control group all three genes were up-regulated from 0.5 to $2 \mathrm{~h}$ of growth in PDB, but declined to only a quarter of the highest expression levels after 4 to $8 \mathrm{~h}$. However, in all of time points tested, the expression of three genes was strongly induced by

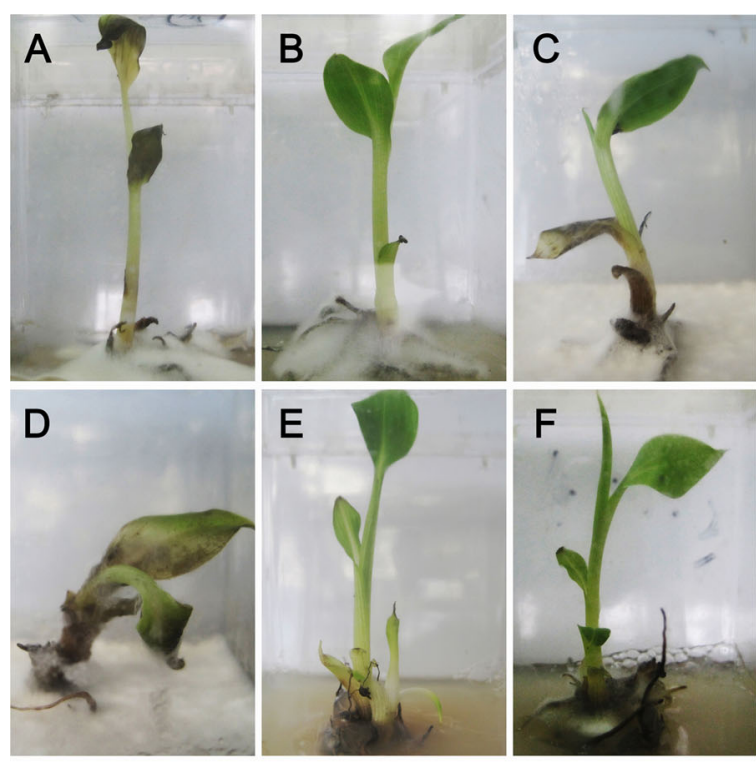

G

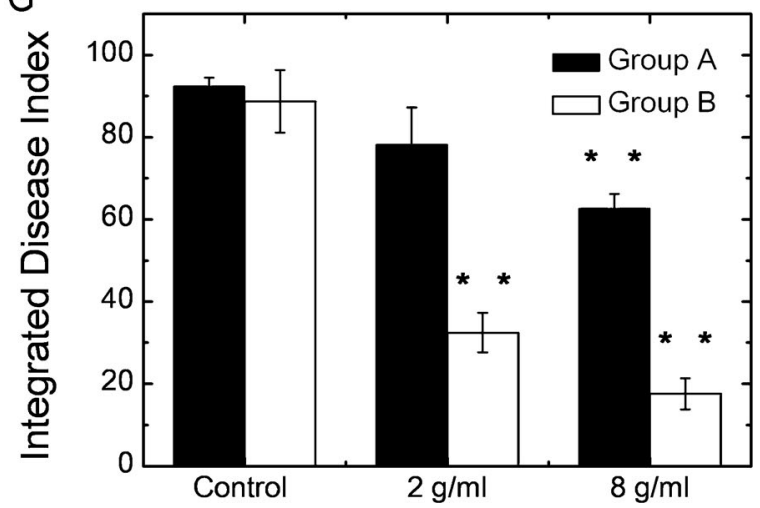

Fig. 7 Bio-control test of CLREs on Fusarium wilt of banana in vitro. In the test to simulate intercropping (a, b and $\mathbf{c})$, Foc TR4 mycelia treated with $8 \mathrm{~g} / \mathrm{ml}$ (b) and $2 \mathrm{~g} / \mathrm{ml}$ (c) CLREs could grow on plant tissue growing out of the medium. In the crop rotation simulation experiment (d, e and f), mycelial growth was completely inhibited by $8 \mathrm{~g} / \mathrm{ml}$ CLREs (e), and significantly reduced by $2 \mathrm{~g} /$ $\mathrm{ml}(\mathbf{f})$. g: quantitative analysis of IDI (\%) in the intercropping (Group A) and crop rotation (Group B) simulation experiment. Data are represented as the mean $\pm \mathrm{SE}$, and the asterisks represent statistically significant differences at $P<0.05$ (*) or $P<0.01$ (**)
CLRE exposure (Fig. 6a-c). These results indicate that the occurrence of autophagy-related adaptive responses was induced by CLREs exposure.

\section{Bio-control effects of CLREs in vitro}

Above, we confirmed the presence of an adaptive response to CLREs exposure. In light of our results, we considered that the reasonable method was important for the effective control of Foc TR4 using antifungal compounds from Chinese leek. In the field, traditional measures such as the intercropping and crop rotation of banana and Chinese leek were used. In this study, in vitro experiments were designed to simulate the above mentioned bio-control methods, and investigate the bio-control efficiency of CLREs (Fig. 7). Notably, the highest control efficacy was achieved by simulating crop rotation using $8 \mathrm{~g} / \mathrm{ml} \mathrm{CLREs.} \mathrm{In} \mathrm{the} \mathrm{control,} \mathrm{symp-}$ toms of banana Fusarium wilt appeared 5 days after inoculation with Foc TR4, and most of the plantlets died within 15 days of inoculation (Fig. 7a and d), with an IDI value of $92.4 \pm 2.1$ (Fig. $7 \mathrm{~g}$ ). In the crop rotation simulation experiment, the IDI values were $25.35 \pm 5.64$ and $17.61 \pm 3.77$ for 2 and $8 \mathrm{~g} / \mathrm{ml}$ CLREs treatment, respectively. In the intercropping simulation experiment, the IDI values were $78.24 \pm 8.94$ and $62.7 \pm 3.62$, respectively (Fig. $7 \mathrm{~g}$ ), mycelia could grow on plantlet tissue that did not penetrate the medium. These results further verified the toxicity of CLREs and the adaptive responses of Foc TR4.

\section{Allelochemicals and its bioactivity}

The selection of antifungal compounds from CLREs is important for further application and research. The volatile phase had been confirmed to exhibit greater inhibitory effects (Fig. 8(1)). In addition, 35 compounds were isolated and identified from the volatile components of the CLREs via GC/MS analysis. Of these, the relative contents of nine compounds were higher than $1 \%$ (Table 2). The main components of the volatiles were sulfur and phenolic compounds, which accounted for $77.3 \%$ and $8.77 \%$ of the total peak area, respectively. Other components including esteric and heterocyclic compounds, which together accounted for $13.93 \%$ of the total peak area. Higher concentrations of pure compounds such as dimethyl trisulfide $(32.12 \%)$, dimethyl disulfide $(23.95 \%)$, 2-propenyl methyl disulfide (10.37\%), 2-propenyl 
Fig. 8 Bioactivities of volatiles and pure compounds from CLREs. (1): Compared to the control (a), most of conidia could be labeled with FDA, which indicates that the viability of FOC TR4 was not significantly reduced by $24 \mathrm{~h}$ of treatment with $8 \mathrm{~g} / \mathrm{ml}$ non-volatiles (b).

However, they were significantly inhibited by treatment with $8 \mathrm{~g} / \mathrm{ml}$ volatiles (c). Scale bars $=50 \mu \mathrm{m}$. (2): Quantitative analysis of the bioactivity of four pure compounds extracted from the volatile CLREs. The data are represented as the mean $\pm \mathrm{SE}$ of three replicates, and the asterisks indicate significant differences from the control groups, when $P<0.05\left(^{*}\right)$ or $P<0.01(* *)$
(1)
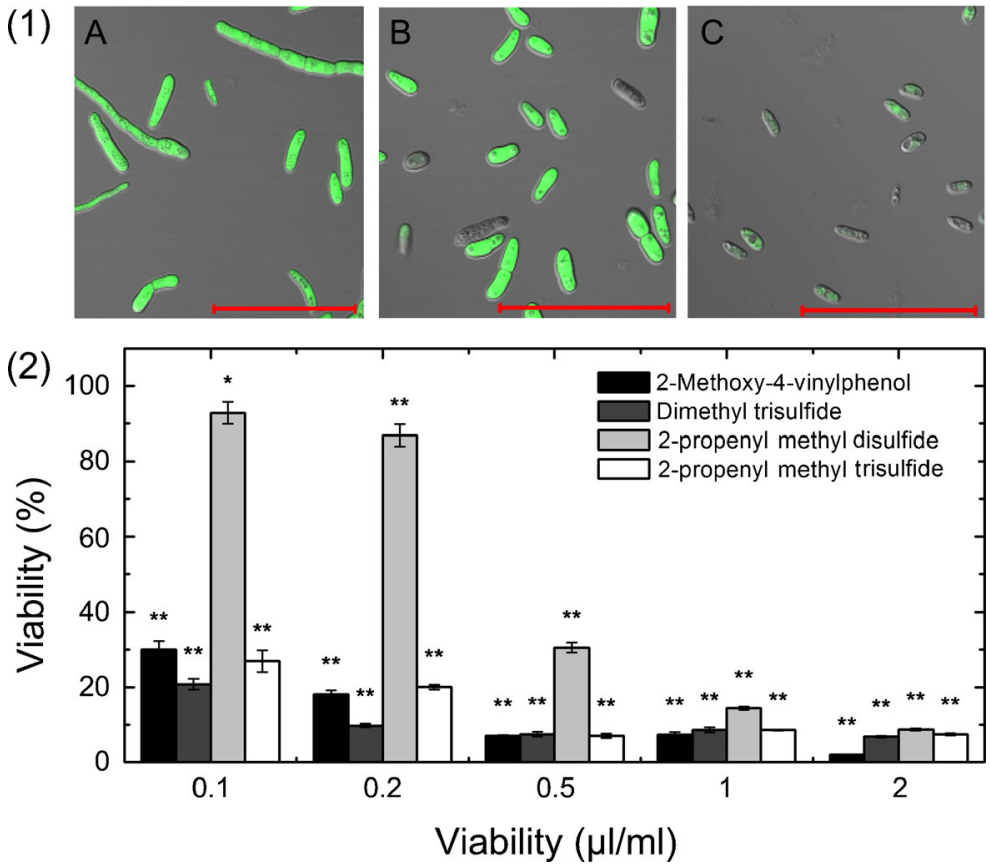

methyl trisulfide (5.84 \%), and 2-methoxy-4vinylphenol $(8.77 \%)$ were identified from among the volatiles.

All four tested volatile compounds had inhibitory effects on Foc TR4 viability, but 2-propenyl disulfide exhibited weaker bioactivity than the other three compounds (Fig. 8 (2)). The viability of Foc TR4 was reduced to less than $10 \% 24 \mathrm{~h}$ after the application of $0.5 \mu \mathrm{l} / \mathrm{ml}$ 2-methoxy-4-vinylphenol, dimethyl trisulfide, and 2-propenyl methyl trisulfide.

\section{Discussion}

Chinese leek is widely used to control Fusarium wilt of banana in southern China (Huang et al. 2012; Zhang et al. 2013). However, there are still limitations to its application, because the mechanism and antifungal compounds behind the control of Fusarium by Chinese leek remain unclear. In this study, we investigated the mechanism by which CRLEs cause cell death, and the mechanism behind the antagonistic response of Foc TR4.
Table 2 Components and contents of root exudates

\begin{tabular}{|c|c|c|c|c|}
\hline Type of compounds & $\begin{array}{l}\text { Retention } \\
\text { time (min) }\end{array}$ & $\begin{array}{l}\text { Molecular } \\
\text { formula }\end{array}$ & Compound name & $\begin{array}{l}\text { Relative } \\
\text { content (\%) }\end{array}$ \\
\hline \multirow{6}{*}{$\begin{array}{l}\text { Sulfur compounds } \\
\quad(77.3 \%)\end{array}$} & 10.07 & $\mathrm{C}_{2} \mathrm{H}_{6} \mathrm{~S}_{3}$ & Dimethyl trisulfide & 32.12 \\
\hline & 5.34 & $\mathrm{C}_{2} \mathrm{H}_{6} \mathrm{~S}_{2}$ & Disulfide, dimethyl & 23.95 \\
\hline & 8.59 & $\mathrm{C}_{4} \mathrm{H}_{8} \mathrm{~S}_{2}$ & Disulfide, methyl 2-propenyl & 10.37 \\
\hline & 12.87 & $\mathrm{C}_{4} \mathrm{H}_{8} \mathrm{~S}_{3}$ & Trisulfide, methyl 2-propenyl & 5.84 \\
\hline & \multirow[t]{2}{*}{5.03} & \multirow[t]{2}{*}{$\mathrm{C}_{3} \mathrm{H}_{6} \mathrm{OS}$} & Methyl thiolacetate & 1.38 \\
\hline & & & Others & 3.64 \\
\hline $\begin{array}{l}\text { Phenolic compounds } \\
\quad(8.77 \%)\end{array}$ & 19.37 & $\mathrm{C}_{9} \mathrm{H}_{10} \mathrm{O}_{2}$ & 2-Methoxy-4-vinylphenol & 8.77 \\
\hline \multirow[t]{4}{*}{ Others (13.93) } & 12.26 & $\mathrm{C}_{10} \mathrm{H}_{18} \mathrm{O}$ & $\begin{array}{l}\text { 1,6-Octadien-3-ol, } \\
\text { 3,7-dimethyl- }\end{array}$ & 3.94 \\
\hline & 24.04 & $\mathrm{C}_{14} \mathrm{H}_{10}$ & Phenanthrene & 2.77 \\
\hline & \multirow[t]{2}{*}{20.78} & \multirow[t]{2}{*}{$\mathrm{C}_{13} \mathrm{H}_{10}$} & 1H-Phenalene & 1.2 \\
\hline & & & Others & 6.02 \\
\hline
\end{tabular}


Toxicity of CLREs to Foc TR4

The antifungal activity of Chinese leek leaf and root extracts had been confirmed (Zhang et al. 2013). Our results further revealed that the viability and germination of Foc TR4 conidia were significantly suppressed by treatment with $2 \mathrm{~g} / \mathrm{ml}$ of CLREs. Thus, we suggested that antifungal compounds secreted by roots of Chinese leek played an important role in the efficiency of Fusarium control via intercropping and crop rotation. The viability of Foc TR 4 decreased by 50 and $10 \%$ when treated with 2 and $8 \mathrm{~g} / \mathrm{ml}$ of CLREs, respectively. Thus, these two concentrations were used for further study. Although it is difficult to calculate the relationship between the concentrations tested and secretion in soil, we suggest better control efficiency in field. CLREs were only collected from the hydroponic system for 20 day. However, Chinese leeks can be grown in the field for as long as 3 to 5 years, during which root exudates could be secreted continuously.

Probable mechanism of $F O c$ TR 4 cell death induced by CLREs

Fungal cell death could be elicited by antifungal compounds and environmental stress (Sharon et al. 2009). In most cases, early features of apoptotic-like cell death were observed. Our results showed that early responses such as ROS bursting and $\Delta \Psi \mathrm{m}$ decreases in Foc TR4 were activated by exposure to CLREs (Fig. 3). As a primary cell death regulator, ROS play a crucial role in cell death and are involved in many of the vital physiological signaling pathways of filamentous fungi (Madeo et al. 2004; Carmona-Gutierrez et al. 2010). They can be produced by the plasma membrane, mitochondria, and other cellular organelles and compartments (Kaelin 2005). During abiotic and biotic stress, ROS accumulation also induced a number of reactions including apoptosis. Plagiochin E-induced ROS accumulation in cells leads to chromatin condensation, DNA fragmentation, and the oxidation of the mitochondrial pores, then mediates apoptosis (Simon et al. 2000; Wu et al. 2010). Furthermore, nuclei of Foc TR4 were stained with PI along with ROS accumulation, which indicated of the occurrence of cell death (Fig. 3). In addition, energy dissipation in the mitochondria has frequently been regarded as a decisive event in apoptosis that regulates many of the key proteins and genes associated with cell death, such as cytochrome $c$, Omi/hTRa2, and the Bcl-2 family (Kroemer et al. 2007). The decrease of $\Delta \Psi \mathrm{m}$ in Foc TR4 exposed to CLREs occurred after an increase in ROS, which indicated that ROS accumulation was an important process underlying the early stages of CLREsinduced cell death. Overall, we speculated that apoptoticlike cell death was elicited by exposure to CLREs through the accumulation of ROS and mitochondrial impairment. However, to determine whether apoptosis occurs under these conditions, detailed study of the mechanism behind the effect of pure compounds from CLREs on $F O C$ TR 4 was required.

A number of antifungal drugs have been shown to target special sites and processes such as the cell wall, plasma membrane, or the synthesis of nucleic acids or proteins (Steffens et al. 1996). The expression of CYP512 and CYP51-3, related to membrane integrity, was inhibited by CLREs (Fig. 5). The depolarization of the membrane structure also induced intracellular $\mathrm{Ca}^{2+}$ changes and oxidative bursts (Cho et al. 2013; Risso et al. 1998). Thus, we suggest that damage to plasma membrane integrity is another important early feature of CLRE-induced cell death, due to their high affinity for fungal ergosterol when Foc TR4 was exposed to CLREs.

\section{Adaptive response of Foc TR4 induced by CLREs}

The adaptive responses of fungi are critical for the survival of continuous exposure to physical and chemical stresses such as fungicide application (Gonçalves et al. 2009; Pillai et al. 2014; Santos et al. 2009). Autophagy, which continuously recycles most cellular constituents, is a major response to both extracellular and intracellular stress (Andreas Roetzer et al. 2010; Mizushima and Klionsky. 2007; Tolkovsky 2009). In Aspergillus nidulans and Chlamydomonas reinhardtii cells, autophagy induced by either carbon starvation or the antifungal drug rapamycin, contributed to the activation of some effectors for survival (Kim et al. 2011; Pérez-Pérez et al. 2010). Autophagy has also been verified to play an important role in the survival of higher eukaryotes (Kim et al. 2009). For Foc TR4, the expression of three vital genes responsible for autography was significantly up-regulated after $4 \mathrm{~h}$ of CLREs treatment (Fig. 6). Furthermore, in the simulation of intercropping, the mycelia of Foc TR4 could grow on banana plantlet tissues outside of the CLREs medium (Fig. 6e and f). Taken together, our observations revealed that CLREs could induce an adaptive response in Foc TR4. 
Antifungal components of CLREs

The purification of antifungal compounds from plants or microorganisms and their application has long been considered an important tool for the effective control of plant diseases (Lavermicocca et al. 2000). Sulfur and phenolic compounds are the major components of volatiles in Chinese leek leaves, roots, and root exudates (Table 2; Pino et al. 2001; Zhang et al. 2013). Sulfur-containing compounds extracted from a number of plants exhibit broad-spectrum bioactivity against fungi and bacteria (Kim et al. 2006; Kyung 2012; Tandon et al. 2009). Our results further verified the strong inhibitory effects of all four compounds in vitro (Fig. 8 and Table 2). Although the inhibitory effects of four sulfur compounds, including dimethyl disulfide, have recently been reported (Zhang et al. 2013), we have verified the bioactivity of 2methoxy-4-vinylphenol against Foc TR4. In addition, we suggest that the sulfur and phenolic compounds released from Chinese leek contributed to the inhibition of Foc TR4 growth in the field.

Thus, we verified the highly inhibitory effects of CLREs on Foc TR4 growth and development. During the inhibitory process, the accumulation of ROS, decrease in $\Delta \Psi \mathrm{m}$, and impairment of membrane integrity were activated. Conversely, adaptive Foc TR4 responses such as autophagy were induced by exposure to CLREs. The sulfur compounds and 2-methoxy-4vinylphenol released from CLREs contributed to their effects.

\begin{abstract}
Acknowledgments We thank Dr. Zhongjian Chen, Chunzhen Chen and Weina Zhang for valuable comments and suggestions during CLSM assays and the preparation of the manuscript. We also thank Dr. Qing Ye's group for their assistance with osmotic pressure assays and valuable discussions. This work was supported by 948 Project from Ministry of Agriculture of China No. 2011G16; International Collaborative Project from Ministry of Science and Technology of China No. 2013DFB30400 and the National Natural Science Foundation of China No. 30971991 and 31272151 .
\end{abstract}

Open Access This article is distributed under the terms of the Creative Commons Attribution 4.0 International License (http://creativecommons.org/licenses/by/4.0/), which permits unrestricted use, distribution, and reproduction in any medium, provided you give appropriate credit to the original author(s) and the source, provide a link to the Creative Commons license, and indicate if changes were made.

\section{References}

Alvarez, F. J., Douglas, L. M., \& Konopka, J. B. (2007). Sterolrich plasma membrane domains in fungi. Eukaryotic Cell, 6(5), 755-763.

Bolard, J. (1991). Mechanism of action of an anti-Candida drug: amphotericin B and its derivatives. In Candida albicans (pp. 214-238). Springer Berlin Heidelberg.

Bowman, S. M., \& Free, S. J. (2006). The structure and synthesis of the fungal cell wall. Bioessays, 28(8), 799-808.

Carmona-Gutierrez, D., Eisenberg, T., Büttner, S., Meisinger, C., Kroemer, G., \& Madeo, F. (2010). Apoptosis in yeast: triggers, pathways, subroutines. Cell Death and Differentiation, 17(5), 763-773.

Cho, J., Choi, H., Lee, J. Y., Kim, M. S., Sohn, H. Y., \& Lee, D. G. (2013). The antifungal activity and membrane-disruptive action of dioscin extracted from Dioscorea nipponica. Biochimica et Biophysica Acta (BBA) - Biomembranes, 1828(3), 1153-1158.

Fourie, G., Steenkamp, E. T., Ploetz, R. C., Gordon, T. R., \& Viljoen, A. (2011). Current status of the taxonomic position of Fusarium oxysporum formae specialis cubense within the Fusarium oxysporum complex. Infection, Genetics and Evolution, 11(3), 533-542.

Glick, D., Barth, S., \& Macleod, K. F. (2010). Autophagy: cellular and molecular mechanisms. The Journal of Pathology, 221(1), 3-12.

Gonçalves, S. C., Martins-Loução, M. A., \& Freitas, H. (2009). Evidence of adaptive tolerance to nickel in isolates of Cenococcum geophilum from serpentine soils. Mycorrhiza, 19(4), 221-230.

Huang, Y. H., Wang, R. C., Li, C. H., Zuo, C. W., Wei, Y. R., Zhang, L., \& Yi, G. J. (2012). Control of fusarium wilt in banana with Chinese leek. European Journal of Plant Pathology, 134(1), 87-95.

Jones, K. H., \& Kniss, D. A. (1987). Propidium iodide as a nuclear counterstain for immunofluorescence studies on cells in culture. Journal of Histochemistry and Cytochemistry, 35(1), 123-125.

Kaelin, W. G. (2005). ROS: really involved in oxygen sensing. Cell Metabolism, 1(6), 357-358.

Kim, S., Kubec, R., \& Musah, R. A. (2006). Antibacterial and antifungal activity of sulfur-containing compounds from Petiveria alliacea L. Journal of Ethnopharmacology, 104(1), 188-192.

Kim, Y. G., Kim, J. Y., Mohan, C., \& Lee, G. M. (2009). Effect of $\mathrm{Bcl}-\mathrm{xL}$ overexpression on apoptosis and autophagy in recombinant Chinese hamster ovary cells under nutrient-deprived condition. Biotechnology and Bioengineering, 103(4), 757766.

Kim, Y., Islam, N., Moss, B. J., Nandakumar, M. P., \& Marten, M. R. (2011). Autophagy induced by rapamycin and carbonstarvation have distinct proteome profiles in Aspergillus nidulans. Biotechnology and Bioengineering, 108(11), 2705-2715.

Kroemer, G., Galluzzi, L., \& Brenner, C. (2007). Mitochondrial membrane permeabilization in cell death. Physiological Reviews, 87(1), 99-163.

Kyung, K. H. (2012). Antimicrobial properties of allium species. Current Opinion in Biotechnology, 23(2), 142-147. 
Lavermicocca, P., Valerio, F., Evidente, A., Lazzaroni, S., Corsetti, A., \& Gobbetti, M. (2000). Purification and characterization of novel antifungal compounds from the sourdough Lactobacillus plantarum strain 21B. Applied and Environmental Microbiology, 66(9), 4084-4090.

Li, C., Chen, S., Zuo, C., Sun, Q., Ye, Q., Yi, G., \& Huang, B. (2011). The use of GFP-transformed isolates to study infection of banana with Fusarium oxysporum f. sp. cubense race 4. European Journal of Plant Pathology, 131(2), 327-340.

Li, C. Y., Mostert, G., Zuo, C. W., Beukes, I., Yang, Q. S., Sheng, O., \& Yi, G. J. (2013a). Diversity and Distribution of the Banana Wilt Pathogen Fusarium oxysporum F. Sp. cubense in China. Fungal Genomics \& Biology.

López-Berges, M. S., Rispail, N., Prados-Rosales, R. C., \& Di Pietro, A. (2010). A nitrogen response pathway regulates virulence functions in Fusarium oxysporum via the protein kinase TOR and the bZIP protein MeaB. The Plant Cell, 22(7), 2459-2475.

López-Berges, M. S., Capilla, J., Turrà, D., Schafferer, L., Matthijs, S., Jöchl, C., \& Di Pietro, A. (2012). HapXmediated iron homeostasis is essential for rhizosphere competence and virulence of the soilborne pathogen Fusarium oxysporum. The Plant Cell, 24(9), 3805-3822.

Madeo, F., Herker, E., Wissing, S., Jungwirth, H., Eisenberg, T., \& Fröhlich, K. U. (2004). Apoptosis in yeast. Current Opinion in Microbiology, 7(6), 655-660.

Mizushima, N., \& Klionsky, D. J. (2007). Protein turnover via autophagy: implications for metabolism*. Annual Review of Nutrition, 27, 19-40.

Molina, A. B., Fabregar, E., Sinohin, V. G., Yi, G., \& Viljoen, A. (2007, September). Recent occurrence of Fusarium oxysporum f. sp. cubense tropical race 4 in Asia. In International Symposium on Recent Advances in Banana Crop Protection for Sustainable Production and Improved Livelihoods 828 (pp. 109-116).

Moore, N. Y., Bentley, S., \& Smith, L. J. (2001). Fusarium wilt of banana: global problems and perspectives. In International Workshop on the Banana Fusarium Wilt Disease, Genting Highlands Resort (Malaysia), 18-20 Oct 1999.

Ozel, M. Z., \& Kaymaz, H. (2004). Superheated water extraction, steam distillation and Soxhlet extraction of essential oils of Origanum onites. Analytical and Bioanalytical Chemistry, 379(7-8), 1127-1133.

Pérez-Pérez, M. E., Florencio, F. J., \& Crespo, J. L. (2010). Inhibition of target of rapamycin signaling and stress activate autophagy in Chlamydomonas reinhardtii. Plant Physiology, 152(4), 1874-1888.

Pillai, S., Behra, R., Nestler, H., Suter, M. J. F., Sigg, L., \& Schirmer, K. (2014). Linking toxicity and adaptive responses across the transcriptome, proteome, and phenotype of Chlamydomonas reinhardtii exposed to silver. Proceedings of the National Academy of Sciences, 111(9), 3490-3495.

Pinan-Lucarré, B., Balguerie, A., \& Clavé, C. (2005). Accelerated cell death in Podospora autophagy mutants. Eukaryotic Cell, 4(11), 1765-1774.

Pino, J. A., Fuentes, V., \& Correa, M. T. (2001). Volatile constituents of Chinese chive (Allium tuberosum Rottl. ex Sprengel) and rakkyo (Allium chinense G. Don). Journal of Agricultural and Food Chemistry, 49(3), 1328-1330.
Ploetz, R. C. (1990). Population biology of Fusarium oxysporum f. sp. cubense. In Fusarium wilt of banana. (pp. 63-76). APS Press.

Ploetz, R. C. (2006). Fusarium-induced diseases of tropical, perennial crops. Phytopathology, 96(6), 648-652.

Richetta, C., \& Faure, M. (2013). Autophagy in antiviral innate immunity. Cellular Microbiology, 15(3), 368-376.

Risso, A., Zanetti, M., \& Gennaro, R. (1998). Cytotoxicity and apoptosis mediated by two peptides of innate immunity. Cellular Immunology, 189(2), 107-115.

Roetzer, A., Gratz, N., Kovarik, P., \& Schüller, C. (2010). Autophagy supports Candida glabrata survival during phagocytosis. Cellular Microbiology, 12(2), 199-216.

Santos, P. M., Simões, T., \& Sá-Correia, I. (2009). Insights into yeast adaptive response to the agricultural fungicide mancozeb: a toxicoproteomics approach. Proteomics, 9(3), 657-670.

Semighini, C. P., Hornby, J. M., Dumitru, R., Nickerson, K. W., \& Harris, S. D. (2006). Farnesol-induced apoptosis in Aspergillus nidulans reveals a possible mechanism for antagonistic interactions between fungi. Molecular Microbiology, 59(3), 753-764.

Sharon, A., Finkelstein, A., Shlezinger, N., \& Hatam, I. (2009). Fungal apoptosis: function, genes and gene function. FEMS Microbiology Reviews, 33(5), 833-854.

Simon, H. U., Haj-Yehia, A., \& Levi-Schaffer, F. (2000). Role of reactive oxygen species (ROS) in apoptosis induction. Apoptosis, 5(5), 415-418.

Smith, L. J., Smith, M. K., Tree, D., O’Keefe, D., \& Galea, V. J. (2008). Development of a small-plant bioassay to assess banana grown from tissue culture for consistent infection by Fusarium oxysporum f. sp. cubense. Australasian Plant Pathology, 37(2), 171-179.

Steffens, J. J., Pell, E. J., \& Tien, M. (1996). Mechanisms of fungicide resistance in phytopathogenic fungi. Current Opinion in Biotechnology, 7(3), 348-355.

Su, H. J., Hwang, S. C., \& Ko, W. H. (1986). Fusarial wilt of Cavendish bananas in Taiwan. Plant Disease, 70(9), 814-818.

Sundriyal, S., Sharma, R. K., \& Jain, R. (2006). Current advances in antifungal targets and drug development. Current Medicinal Chemistry, 13(11), 1321-1335.

Tandon, V. K., Maurya, H. K., Mishra, N. N., \& Shukla, P. K. (2009). Design, synthesis and biological evaluation of novel nitrogen and sulfur containing hetero-1, 4-naphthoquinones as potent antifungal and antibacterial agents. European Journal of Medicinal Chemistry, 44(8), 3130-3137.

Tawara, S., Ikeda, F., Maki, K., Morishita, Y., Otomo, K., Teratani, N., \& Kuwahara, S. (2000). In vitro activities of a new lipopeptide antifungal agent, FK463, against a variety of clinically important fungi. Antimicrobial Agents and Chemotherapy, 44(1), 57-62.

Tolkovsky, A. M. (2009). Mitophagy. Biochimica et Biophysica Acta (BBA) - Molecular Cell Research, 1793(9), 1508-1515.

Viljoen, A. (2002). The status of Fusarium wilt (Panama disease) of banana in South Africa: review article. South African Journal of Science, 98(7-8), 341.

Washington, W. S., Engleitner, S., Boontjes, G., \& Shanmuganathan, N. (1999). Effect of fungicides, seaweed extracts, tea tree oil, and fungal agents on fruit rot and yield in strawberry. Animal Production Science, 39(4), 487-494. 
Wessels, J. G. H. (1994). Developmental regulation of fungal cell wall formation. Annual Review of Phytopathology, 32(1), 413-437.

Wheeler, K. A., Hurdman, B. F., \& Pitt, J. I. (1991). Influence of $\mathrm{pH}$ on the growth of some toxigenic species of Aspergillus, Penicillium and Fusarium. International Journal of Food Microbiology, 12(2), 141-149.

Wu, Y. L., Yi, G. J., \& Peng, X. X. (2010). Rapid screening of Musa species for resistance to Fusarium wilt in an in vitro bioassay. European Journal of Plant Pathology, 128(3), 409415.
Yamada, T., Egashira, N., Imuta, M., Yano, T., Yamauchi, Y., Watanabe, H., \& Oishi, R. (2010). Role of oxidative stress in vinorelbine-induced vascular endothelial cell injury. Free Radical Biology and Medicine, 48(1), 120-127.

Zhang, W., \& Chen, W. (2011). Role of salicylic acid in alleviating photochemical damage and autophagic cell death induction of cadmium stress in Arabidopsis thaliana. Photochemical \& Photobiological Sciences, 10(6), 947-955.

Zhang, H., Mallik, A., \& Zeng, R. S. (2013). Control of panama disease of banana by rotating and intercropping with Chinese chive (Allium tuberosum Rottler): role of plant volatiles. Journal of Chemical Ecology, 39(2), 243-252. 